\title{
2 次元フォーストプリュームの水理特性
}

室田 明*. 中辻啓二**. 石田悦一***. 日置洋平****

\section{1.まえがき}

浅水海域に水中放流される下水処理水の挙動ならびに 混合希釈特性の解明1) を直接の契機として著者等は研究 を始め, 前報 ${ }^{2)}$ では 2 次元フォーストプリュームの連行 係数の変化を解析的に求める微分・積分混成モデルを展 開した，噴流からプリュームへと遷移するフォーストプ リュームでは連行係数は流下とともに増大する傾向にあ る.これは，現象論的にみれば，浮力流束が運動量流束 に対して優勢になるとともにプリューム軸が緩慢にゆら ぎ始めることと対応している.このゆ゙்き現象が噴流と プリニームの連行能の差異に直接的に関与していると推 察されているが，その機構は未だ明確ではない。

本研究では，フォーストプリュームの連行機構を解明 する前段階として，基礎的な水理実験を実施し，その基 本特性を明確にする.ささらに，同時計測によって温度場 の時空間構造を明らかにしゆらぎ現象についても言及 する.

\section{2. 実験装置および水理諸元}

実験は 図一1 に示す前面 ガラス張の水槽（高さ 130 $\mathrm{cm}$, 幅 $90 \mathrm{~cm}$, 奥行 $90 \mathrm{~cm})$ の前面 $15 \mathrm{~cm}$ を仕切って 行った. ヒーターで加熱した温水を恒温水槽で攪汼し一 定温度に調節した後に，ヘッドタンクを通して縮流スリ ット（幅 $0.4 \mathrm{~cm}$, 長さ $15 \mathrm{~cm}$ ) よりフォーストプリュー ムとして鉛直上向きに放流した.プリュームの温度はス リット内に設置したサーミスターで，また流量はバルブ (a)で調節し，流量計 B で測定した. 熱収支の不均衡に 原因する界面の低下ならびに対流を抑制するために，周 囲水として水道水をバルブ (c)より供給するとともに， 水槽の前後面で水位差をつけて計測水槽中に下方から上 向きに一様な流れを生起させている．流速と温度は直径 $0.4 \mathrm{~cm}$ の小型プロペラ流速計 (計測技研製) と高感度サ ーミスターを用いて計測した。

水理諸元は表一1に示す.ここに， $U$ : 流速, $W_{0}$ : ス

\footnotetext{
* 正会員 工博 大阪大学教授 工学部土木工学科

** 正会員 工修 大阪大学講師 工学部土木工学科

*** 正会員 工修 北海道開発局旭川開発建設部

**** 学生員 大阪大学大学院工学研究科前期課程学生
}

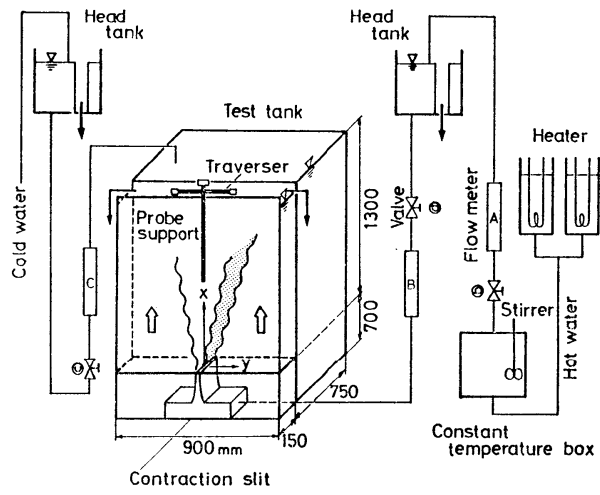

図-1 実験装置

表一1 水理諸元

\begin{tabular}{l|c|c|c|c|c|c}
\hline \multicolumn{1}{c|}{ Regime } & $\begin{array}{c}U_{0} \\
(\mathrm{~cm} / \mathrm{s})\end{array}$ & $\begin{array}{c}\Delta \rho_{0} \\
\left(\mathrm{~g} / \mathrm{cm}^{3}\right)\end{array}$ & $F d_{0}$ & $R e_{0}$ & $x / W_{0}$ & $\begin{array}{c}y_{T} \\
(\mathrm{~cm})\end{array}$ \\
\hline Jet & 33.7 & 0.00079 & 68.5 & 977 & 62.5 & 3.85 \\
\hline Intermediate & 21.8 & 0.00590 & 15.5 & 1030 & 75.0 & 3.60 \\
\hline Plume-1 & 16.0 & 0.01520 & 7.0 & 1130 & 87.5 & 3.90 \\
\hline Plume-2 & 8.3 & 0.01426 & 3.5 & 328 & 87.5 & 3.90 \\
\hline
\end{tabular}

リット幅, $\varepsilon\left(=\Delta \rho / \rho_{a}\right)$ : 相対密度差, $F d_{0}=U_{0} / \sqrt{\varepsilon g W_{0}}$ : 密度フルード数, $R e_{0}=U_{0} W_{0} /$ レ : レイノルズ数, $y_{T}$ : 流 下位置 $x / W_{0}$ における温度の半值半幅である. 添字 0 と $a$ はとれぞれ放流口，周囲水の水理諸量を示す.

\section{3. 基本的な水理特性}

\section{（1）平均流速，平均温度差の流下方向莪減特性}

図一2，3 はプリューム軸上の平均流速 $U_{\Phi}$ ならびに 平均温度差 $\Delta T_{\Phi}\left(=T_{\Phi}-T_{a}, T_{a}\right.$ ：周囲水温度）の逓減 特性を示したものである. 縦軸と横軸は Chen・Rodi ${ }^{3}$ の提唱した次式で表わされる無次元量 $U_{*}, T_{*}$ および $X_{*}$ で表示した.

$$
\left.\begin{array}{l}
U_{*}=\frac{U_{\Phi}}{U_{0}} F d_{0}^{2 / 3}\left(\frac{\rho_{0}}{\rho_{a}}\right)^{-1 / 3} \\
T_{*}=\frac{\Delta T_{\Phi}}{\Delta T_{0}} F d_{0}^{2 / 3}\left(\frac{\rho_{0}}{\rho_{a}}\right)^{2 / 3} \\
X_{*}=\frac{x}{W_{0}} F d_{0}^{-4 / 3}\left(\frac{\rho_{0}}{\rho_{a}}\right)^{-1 / 3}
\end{array}\right\}
$$




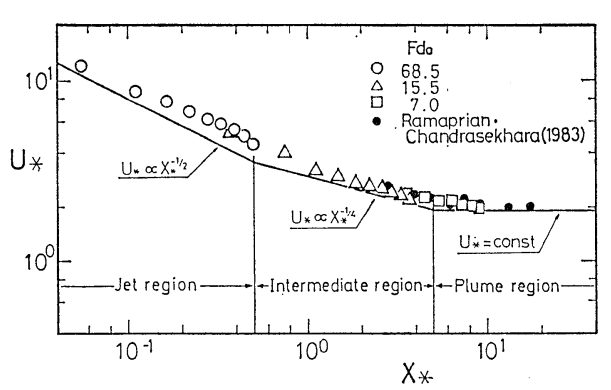

図-2 平均流速の流下方向变化

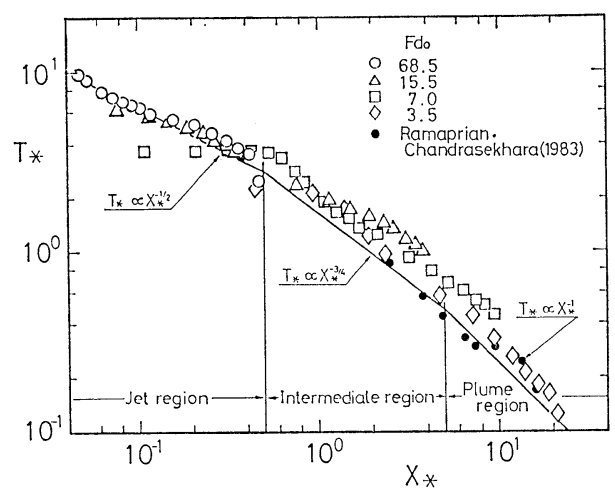

図-3 平均温度差の流下方向変化

Chen・Rodi は噴流あるいはプリュームの各領域に対 して平均流速，平均温度差および乱流フラックスの自己 相似の仮定の下に，支配方程式から $U_{\Phi}$ と $\Delta T_{\Phi}$ の派減 則を求めている. 図中の実線は既往の実験結果と合致す るように求められた彼等の半経験式である.ただし，中 間領域は両領域を補間するように与えられている.

今回の実験值（白抜き記号）ならびに Ramaprian・ Chandrasekhara $^{4}$ （黒塗り記号）の派減率および領域区 分は半経験式とよく合致しており，噴流領域 $\left(x_{*}<0.5\right)$ では $U_{*} \propto X_{*}{ }^{-1 / 2}, T_{*} \propto X^{-1 / 2}, フ^{\prime} ュ$ ニ領域 $\left(5.0<x_{*}\right)$ では $U_{*}=$ 一定, $T_{*} \propto X_{*}^{-1}$ となる. しかし，その值は半 経験式より少し大き目の值を示している. Ramaprian • Chandrasekhara の実験は LDA とサーミスターを併 用した最も精度の高い実験值を提供していることから， Chen R Rodi の提案した半経験式は実験条件の違いある いは水槽の特性によってある程度の許容範囲を有してい るものと考光られる.

噴流とプリューム領域における派減率の違いは主に両 流動形態での周囲水の連行の差異に原因しており，プリ ュームの連行能は噴流と比較して大きいことがわかる.

\section{（2）温度の断面内分布特性}

図一4 は各領域の代表断面で測定した温度の平均值お よび最大值と最小值の断面内分布を示す. 縦軸は各々の 值を中心軸上温度差 $\Delta T_{\Phi}$ で, また横軸は横方向距離 $y$ を温度差の半值半幅 $y_{T}$ で無次元表示している.
平均值 $\Delta T_{\text {mean }}$ の分布はいずれの領域においてもガウ ス分布形となり, 浮力効果の大小と無関係に相似則が成 立していることがわかる.これに対して，最大值 $\Delta T_{\max }$ と最小值 $\Delta T_{\min }$ の分布は各領域で明瞭な違いを示す。 た とえば,最大值の分布では中間流動とプリュームの $y / y_{T}$ $=1.7,2.0$ の位置で急激な減少がみられる，一方，噴流 ではそのような不連続な変化は認められない，また，最 小值の分布では周囲水温度, つまり $\Delta T_{\min }=0.0$ を示す 位置が噴流・中間流動およびプリュームでそれぞれ $y / y_{T}$ =1.15，1.0，0.7 と中心軸に近づく傾向にある. 十分に 発達したプリュームでは周囲水は中心軸にまで達すると いう興味深い結果を Kotsovinos ${ }^{5)}$ は報告している.これ らの最大值と最小值の分布特性から，プリュームでは放 流温水と周囲水の全断面にわたる大規模な横方向流動が 生起しているものと推量できる.

つぎに，図一4 に対応する各断面での乱れ強さ $\sqrt{\bar{\theta}^{2}}$ $\mid \Delta T_{\mathscr{E}}$ の断面内分布を図一 5 に示す. 各流動とも乱れ強 さの分布は中心軸付近で落ち込んでおり， $y / y_{T}=0.0$ で 最小, $y / y_{T}=1.0$ 近傍で最大となる. 浮力効果の大きい ほど， $\sqrt{\bar{\theta}^{2}} / \Delta T_{\Phi}$ の值は大きく，また最大值付近の分布 形は非尖塔的になる. Kotsovinosはプリュームでの乱れ
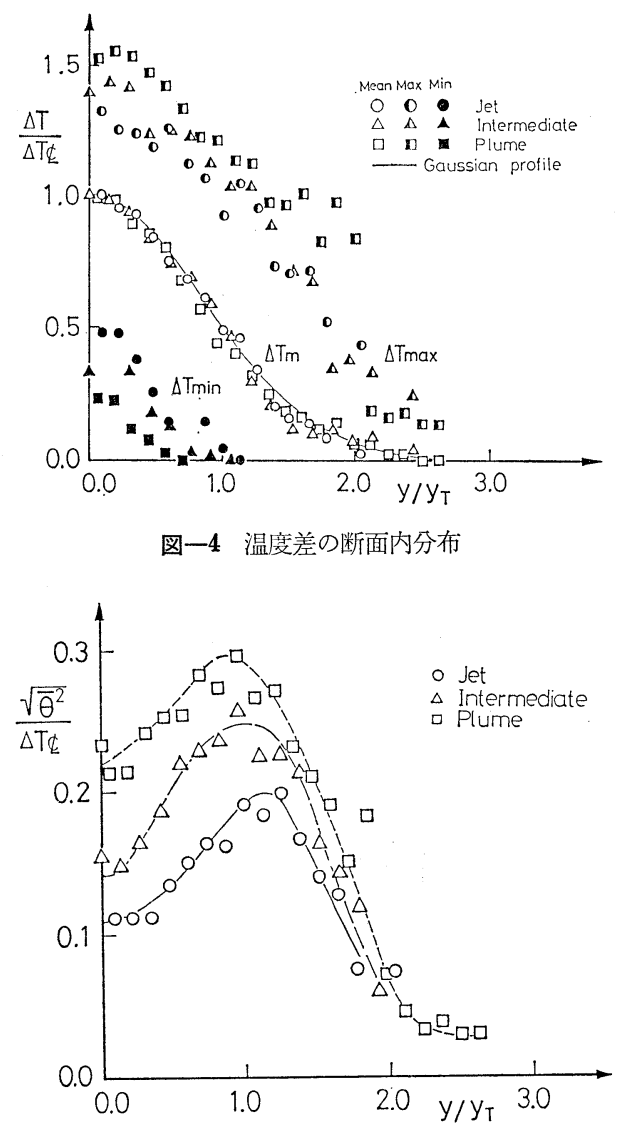

図一5 温度变動の乱れ強さの断面内分布 
強さの分布形は top hat 型になることを，また中込・平 田6)は中心軸付近でピークをとることを報告しているが， 本実験では放流口密度フルード数 $F d_{0}=7.0$ の $x / W_{0}=$ 87.5 の流下位置においてさえ分布形は双頭型でありピ ュアプリュームにまで十分に発達していないことを示し ている.

\section{（3）分離された温度变動の評価}

さて, 図一 4 の $\Delta T_{\max }$ と $\Delta T_{\min }$ の分布特性から，プ リューム内部の乱流運動により中心軸近くの熱い流体塊 が外縁に向って移流し，また周囲水の流体塊がプリュー ムの内部にまで入り込んでくることが推定される。これ は高温水塊と周囲水塊との間久的な温度変動として計測 された時系列に現われ，ある閾值温度を設定することに より放流温水と周囲水とを区分することが可能となる.

次節で述べる方法により温度变動の分散 $\bar{\theta}^{2}$ を放流温 水々周囲水とに分離して $\left(\bar{\theta}^{2}=\bar{\theta}_{h}{ }^{2}+\bar{\theta}_{c}{ }^{2}\right)$, それらの断面 内分布を示したのが図一6である。 $\bar{\theta}_{0}^{2}$ は大規模な横方 向流動によって生起しており, 周囲水流塊の分担する分 散 $\bar{\theta}^{2}$ として理解することが可能である. それゆえ, 周 囲水の連行の貢献を大略評価し得る量となるが， $\bar{\theta}_{c}^{2}$ の 分布は代表スケール $\left(\Delta T_{\Phi}\right.$ や $\left.y_{T}\right)$ で無次元表示する限 りにおいては噴流とプリュームでほとんど差異は認めら れなく，同形となる.すなわち， $\bar{\theta}_{c}^{2} / \Delta T_{\mathbb{C}^{2}}{ }^{2}$ は $y / y_{T}=$ 1.1 付近でピークをもつなだらかな分布を示す.

これに対して， $\bar{\theta}_{h}{ }^{2} / \Delta T_{\Phi^{2}}{ }^{2}$ の分布形は噴流とプリュー ムとでは著しく異なっている. この原因は放流温水内で 生成される $\bar{\theta}_{h}^{2}$ の違いにある. 中込・平田は乱れ強度な らびに乱流熱流束の詳細な測定を行い， $\bar{\theta}^{2}$ の収支式中 の生成項 $-\overline{u \theta} \cdot \partial T / \partial x$ を評価している. それによれば, プ リュームでの $-\overline{u \theta}$ の分布は中心軸付近で大きく, 外縁 に向って派減するのに対して，噴流でのそれは中心軸上 で落ち込んでいる. 加えて, 図一3に示したようにプリ ニームの $\partial T / \partial x$ が噴流と比較して大きいことから, $\overline{u \theta}$ との相乗作用によりプリュームにおけるー $\overline{u \theta} \cdot \partial T / \partial x$ の 值は大きくなる。この結果，プリュームの $\bar{\theta}_{h}{ }^{2}$ の值は $y / y_{T}<1.0$ の範囲で噴流のそれの約 2 倍にもなり, 図一

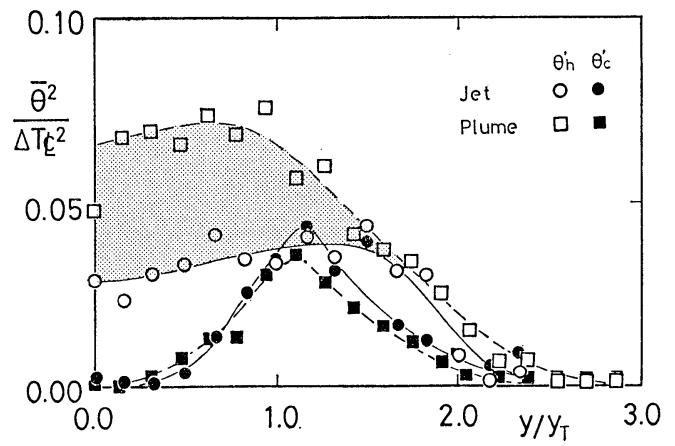

図一6 分離された温度变動の断面内分布
5 の乱れ強さ $\sqrt{\overline{\theta^{2}}} / \Delta T_{\Phi}$ の分布形の違いに貢献してい る.

\section{（4）乱れの間欠性}

乱れ変動が放流温水（乱流状態）か，周囲水（非乱流 状態）かを判別する方法として, 温度変動が設定した闌 值温度 $T_{t h}$ を越えるか否かにより $[1,0]$ の二值で表現 する間欠関数 $I(t)$ がある.この $I(t)$ を用いて, サーミ スターが放流温水内にある時間の占有率 $\gamma$ と放流温水塊 の単位時間当りの通過周波数 $f_{I}$ は次式のように定義で き, 前者は間欠因子, 後者は間欠周波数と称される.

$$
\left.\begin{array}{l}
r(x, y)=\frac{1}{N} \sum_{i=1}^{N} I(x, y, i \Delta t) \\
f_{I}(x, y)=\frac{1}{2 N \Delta t} \sum_{i=1}^{N}\left|\frac{\partial}{\partial t} I(x, y, i \Delta t)\right|
\end{array}\right\}
$$

間欠関数 $I(t)$ は䦨值温度 $T_{t h}$ の関数となる. 閾值温度 の設定に際しては， $y / y_{T} \geqq 1.6$ で測定した温度変動を用 Wて，任意の $T_{t h}-T_{c}+\alpha \Delta T_{\mathbb{E}}(0<\alpha<1)$ に刘して仮に 求められる間欠因子 $\gamma$ と $\alpha$ の間の曲線から変曲点を求 め，その值を閾值とする合理的な方法を採用した。

図一7 は噴流とプリューム各領域の $\gamma$ と $f_{I}$ の断面内 分布を示す. $f_{I}$ は測定断面における代表スケール $U_{\Phi}$ と $y_{T}$ を用いて無次元量 $S t_{I}=f_{I} \cdot y_{T} / U_{\Phi}$ で表示した.

間欠関数 $r$ の分布は $y / y_{T}<0.5$ の範囲で $\gamma \fallingdotseq 1.0$ の 平坦な形状であり，外縁に向かって次第に減少する。 そ の分布は噴流とプリュームでほぼ同形である.これに対 して，ストローハル数 $S t_{I}$ の分布は両流動形態で明瞭に 異なる．噴流では $S t_{I}$ は半間欠点 $(\gamma=0.5)$ でピークと なるガウス分布形になるのに対し，プリュームでは 0.9 $<y / y_{T}<1.9$ の範囲で $S t_{I} \fallingdotseq 0.11$ の平坦な分布形にな る. その值は噴流におけるピーク值の約 $65 \%$ であり， プリュームと噴流の時間スケールの違いがうかがわれ

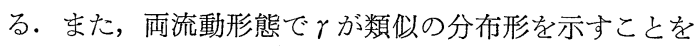
勘案すれば, プリュームでは持続時間 $\left(=2 \gamma / f_{I}\right)$ の長い 温水塊が長周期で間欠的に通過していることが予想され る.これは，著者等》あるいは Kotsovinos が可視観測に より観察した，プリュームのゆらぎ現象を反映している

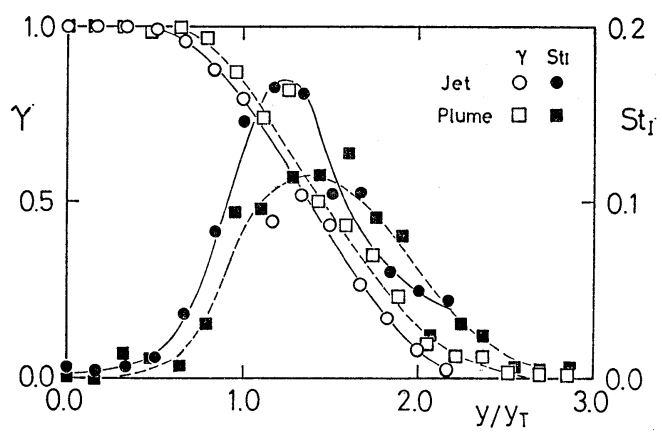

図一7 間欠関数と間欠周波数 


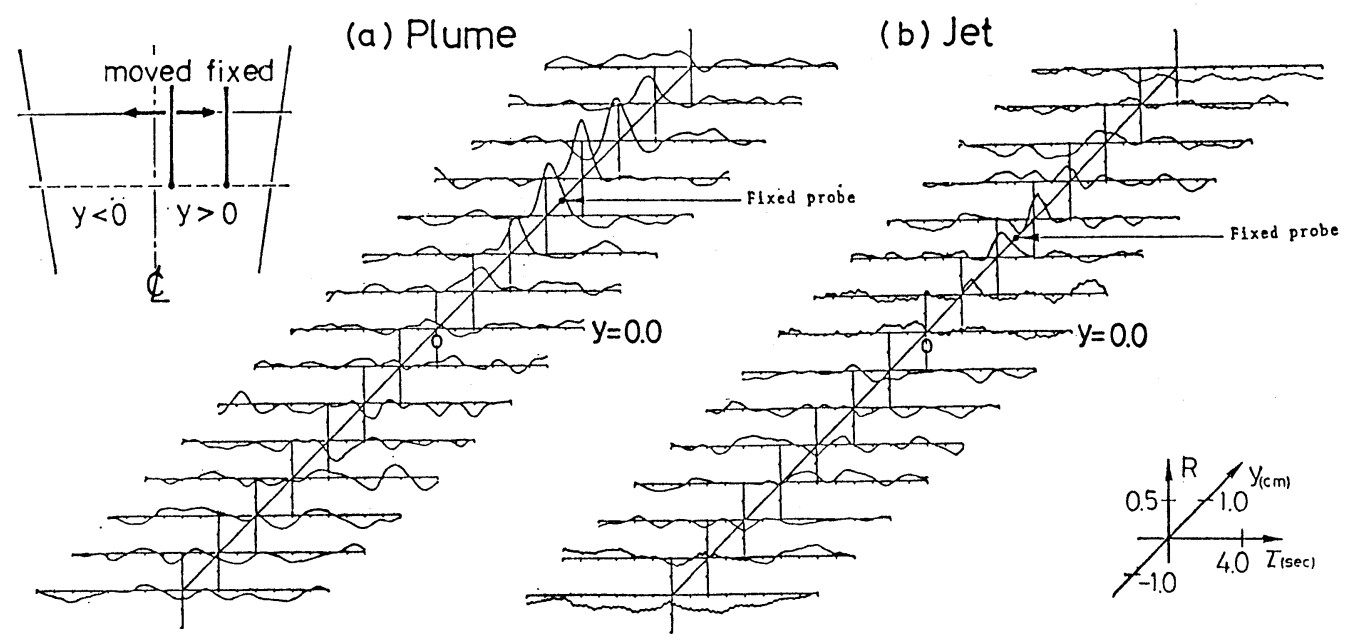

図一8 プリュームと噴流における相互相関関数形

ものと考光られる。

\section{4. 時空間乱れ特性}

プリュームに内在するゆらぎのような時間的・空間的 に変化する流動の構造をさらに明らかにするには，一点 で計測した情報ではたと劣条件付抽出法を駆使したとし ても現象の把握は難しい. そこで図一8 に示すように 2 本のサーミスターを用い，1本を $\sqrt{\overline{\theta^{2}}}$ の值が最大とな る位置に固定し，他の 1 本を断面内で移動させる同時計 測を行った. 得られた空間相関の描く物理像について考 察し，ゆらぎの特性を明らかにする、なお，計測断面は 表一1 に示した Jet, Plume-1 の 2 断面である.

\section{(1) 相互相関関数}

図一8 はプリュームおよび噴流における空間相関を示 したものである. 横軸は遅れ時間, 縦軸は相関係数, 斜 軸は横方向距離を示す.

プリュームにおいては，サーミスターを固定した $y>$ 0 の断面で固定点を中心に最大值 0.8 程度の高い相関値 を示し，中心軸近傍で相関はほとんどなくなる，他方， $y<0$ の断面ではその絶対值は小さいながらも逆に負の 相関を示している. Antonia・Browne ${ }^{8)}$ は平面噴流の組 織構造の解明を目的に流速と温度变動を同時計測してお り, 温度変動の相関係数はとの絶対值は小さいるのの流 速変動の相関係数と対応することを報告している.この ことより， $y<0$ の断面での相関も有意であると判断で き,プリュームの乱流構造は中心軸に対して逆対称とな っていると推量できる.プリュームにおける時空間乱れ 構造をさらに検討するために $y>0$ において正の相関の 最大值が現われる遅れ時間 ての断面内分布を示したのが 図一9である. 横軸は温度の半值半幅で無次元化した横 方向距離を, また綎軸は遅孔時間 $\tau$ を実時間で示す. 遅
れ時間 $\tau$ の分布はサーミスター固定点で，中心軸側より 正から負に遷移する直線となる、いま，ゆらぎの横方向 の移流速度を $V_{c}=\Delta y / \Delta \tau$ で定義するならば，プリュー 厶内で $V_{c} / U_{\mathscr{E}}=0.67$ の一定值となる. この事実より プリュームにおいては乱流構造はプリューム全幅にわた って挙動するゆらぎ現象を呈しているものと推察され る.

一方, 図一8 (b) は同様の解析を噴流に対して適用し た結果である. $y>0$ の断面ではプリュームと同様に固 定点付近で最大となる正の相関值を示すが，その值はお よそ 0.4 程度であり，プリュームのそれと比べて小さ く，且つその相関度の高い範囲孔狭い，さらに，y<0に おいては有意な相関はほとんど認められない。著者らは 中心軸に対して対称な位置に 2 本のサーミスターを設置 する実験も行い，本解析之同様に空間相関を検討した. その結果, プリュームにおいては $\tau=0.0$ の相関係数は $y / y_{T}<1.0$ の範囲で明瞭な負值を示すが，噴流において は有意な相関は認められなかった。このことより, 噴流 における乱流構造は中心軸の両側で独立に挙動している ものと推察される.これらの結果は噴流ではプリューム

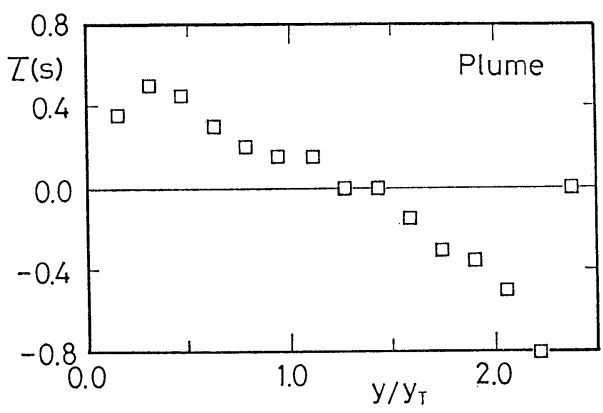

図一9 遅孔時間 $\tau$ の断面内分布 
に観られるような全断面にわたる規模のゆらぎが生じて いないという可視観測の結果とも一致する.

\section{(2) 空間スケール}

図一10 は遅れ時間 $\tau=0.0$ のときの相関係数 $R$ の断 面内分布を示す. プリュームでは噴流に比べて相関係数 の絶対值は大きく, 高い相関度を示す位置は広範囲に及 ぶ. そこで，図一10に示した相関係数を断面内積分す ることによって両流動の乱れの空間スケールを定量的に 評価した. 積分スケール $L$ は次式で定義される.

$$
L=\int_{-\infty}^{\infty} R d y
$$

積分スケールLを温度の半值半幅で無次元化して示す ならば，プリュームと噴流でそれぞれ $L / y_{T}=1.05,0.59$ となる。プリニームでの積分スケールは噴流でのそれの 約 1.8 倍となり，両流動の空間スケールの違いが定量的 にわかる。

中込・平田は流速変動の自己相関関数に基ついた積分 長さスケールを評価することによって同様の結果を得て いる.このことより，ゆらぎ現象はフォーストプリュー ムの乱れスケールの増大をもたらしており，それには浮 力効果が值接的に関与していると結論づけられる。

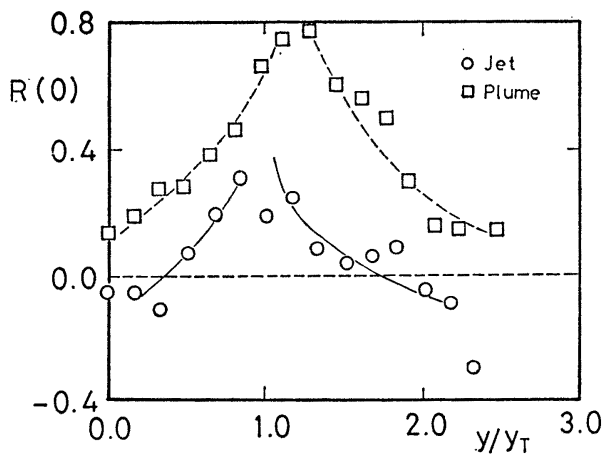

図-10 $\tau=0.0$ の相関係数の断面内分布

\section{5.あとがき}

流下とともに噴流形態からプリューム形態へと遷移す る 2 次元フォーストプリュームの基本特性を水理実験か ら検討した. 流動ならびに混合希釈特性は Chen・Rodi の半経験式にしたがって遷移し, 各流動で自己相似が成 立していることが明らかになった. 温度乱れ変動および 乱れの間欠現象も代表スケール（中心軸上流速, 温度差 および半值半幅）を用いて無次元表示する限りは噴流と プリュームとで相似形となる. 両流動の違いは可視観測 において観察されているゆらぎ現象にあり，間欠周波数 あるいは相互相関関数の断面内分布の差異より定量的に 確かめられた．今後はこのゆらぎ現象が連行機構にいか なる形で関与するかについて検討してゆく予定である.

\section{参 考文 献}

1）室田 明·中辻啓二・石田悦一：浅水海域に放流される下 水処理水の混合希䣋特性について, 第 29 回海講論文集, pp. 604 608, 1982.

2) 室田 明・ 中辻啓二 ・ 日置洋平: 2 次元フォーストプリニ 一ムの微分·積分混成モデル, 第 30 回海講論文集, pp. 571 $575,1983$.

3) Chen, C. J. and W. Rodi: Vertical Turbulent Buoyant Jets, A Review of Experimental Data, Pergamon Press, 83 p., 1980.

4) Ramaprian, B. R. and M. S. Chandrasekhara: Study of Vertical Plane Turbulent Jets and Plumes, IIHR, Report, No. 257, March 1983.

5) Kotsovinos, N. E. and E. J. List: Plane Turbulent Buoyant Jets Part 2. Turbulent Structure, J. Fluid Mech., Vol. 81, Part 1, pp. 45 62, 1977.

6) 中込秀樹 - 平田 賢： 2 次元サーマルプルームの拡散機構, 日本機械学会論文集, 46 巻, 410 号, pp. 2023 2036, 1980.

7）石田悦一・室田 明・中辻啓二・日置洋平： 鉛直上向きプ リュームに観られる渦動とゆらぎ, 第 39 回年次学術講演会 概要集, II-246, 1984.

8) Antonia, R.A. and L. W. Browne: On the Organized Motion of a Turbulent Plane Jets, J. Fluid Mech., Vol. 134, pp. 49 66, 1983. 